\title{
New type of urbanization under the background of rural labor transfer analysis
}

\author{
Wang Dongling, ${ }^{1, a}$, \\ ${ }^{1}$ Shandong Yingcai University, Jinan, 251401, China \\ a E-mail: 40668058@qq.com
}

Keywords: Urbanization; Rural Labour Force; Transferring; Employ

\begin{abstract}
The successful transference of rural China's surplus labors can benefit the development of China's rural economy, and hence accelerate the progress of China's market economy; widen the source of urban labor forces and the demand of market commodities, and hence fasten the course of transforming China's dual economy structure.
\end{abstract}

\section{Introduction}

The new urbanization is an inevitable trend of China's economic and social development and the process of the transfer of rural surplus labor.The transfer of rural surplus labor force is the main problem facing China's modernization process.

The contradiction between the land and the people in China have become increasingly prominent in rural areas has generated a lot of surplus labor. Excessive rural surplus labor force will led directly to the low efficiency of agricultural production and farmers' incomes, restricting the construction of a new socialist countryside and urban-rural coordinated development. Rural million rural laborers need to be transferred, the transfer of rural surplus labor is still an arduous task.To comprehensively promote the construction of a new socialist countryside, the difficulty is the transfer of rural surplus labor force, the key is to strengthen the training of rural labor, and strive to improve the comprehensive quality of the rural labor force, make population pressure into human resource advantages, and the promotion of rural labor to non-agricultural industries and urban orderly transfer of a fundamental solution to the "three agricultural issues" to achieve the harmonious development of urban and rural economic and social.

\section{Lewis model}

Lewis model emphasizes the contribution of industrial high productivity of labor transfer. Lewis created a dual economy of rural surplus labor model in his article "Unlimited labor supply under the conditions of economic development" published in 1954,assume that the Lewis surplus agricultural labor was an unlimited supply the production sector was Divided into the traditional agricultural sector and rural center city as the center of the modern industrial sector, labor transfer from rural to urban is caused by the transformation of the structure of industrial production led to the employment the structural transformation. The accumulation of capital made the scale of the industrial sector continue to expand, the demand for labor is also increasingly expanding, driven by the high marginal productivity of modern industrial,agricultural surplus labor transfer to the industrial sector constantly.Lewis' dual economy model shows the development process in developing countries is the process of the agricultural sector shrinking,industrial sector 
ever-expanding with the transfer of rural surplus labor.

\section{John C.H.Fei and Gustav Ranis}

John C.H.Fei and Gustav Ranis stressed the importance to increase agricultural productivity for labor transfer.In1961,the American economist John C.H.Fei and Ranis published an important paper entitled"A theory of the economic development",on the basis of Lewis' dual economy model, the process the labor flow to the industrial sector is divided into three stages. The first stage is similar to the Lewis model, the state of labor is in unlimited supply; the second stage, the agricultural labor force continues to decrease and agricultural productivity continue to gain, labor supply decreases elasticity; in the third stage, the industrial and agricultural productivity achieve a balance, zero value of the agricultural labor and low the value of labor completely disappeared, to complete the transformation from traditional agriculture to modern agriculture. The models take full account of the agricultural self-development impact to labor transfer. Fei and Ranis that directly think that any change in a production sector productivity must be related to the same rate of strength and quality of technological revolution, and analysis of the growth of the labor surplus economy, should focus on not only changes in the productivity of the industrial sector, but also attention the same expansion of the agricultural sector at the same time.

\section{D.W.Jorgenson's doctrine of consumer demand-driven labor force transfer.}

"In the dual economy" published in1961,Jorgenson (Dale W.Jorgenson) pointed out that technological advances will promote industrial and agricultural sector wage to increase,and therefore industrial and agricultural wage level is not fixed. But Jorgenson point that the wage gap is not the root cause of labor transfer. In 1967, Jorgenson presented the view of consumer demand drive labor transfer in an article entitled "surplus labor and binary economic development", the fundamental transfer of rural labor is that consumer demand changes, the transfer is based on agriculture surplus rather than the exist of that marginal productivity is zero or greater than zero but less than the actual income level of the labor force. People stay in the agricultural sector in order to meet the physical needs for agricultural products, with the farm products remaining, the agricultural sector will lose the tension on the labor, so the labor transfer to the industrial sector of more exuberant demand.

\section{Domestic research}

Domestic "Three Rural Issues" experts and scholars, the Central Policy Research, Policy Research Office of the State Council, the various colleges and universities and provincial research institutes have carried out a lot of research work and the results.

Industrialization and economic development are always accompanied by large-scale rural-urban (Rural----City) labor mobility. This flow will bring income rises, the upgrading of industries, and ultimately to promote the modern sector development, (Nong Zhu, 2002). In China, a large number of rural surplus labor force are tied to the limited arable land, do not treat them from rural transferred out of reasonable use, is not only a waste of labor resources, and make this part of the labor force has become a consumption of social wealth. The "Tenth Five-Year" period is the peak period of growth in the labor force in China, and for a long period of time in the future. With the continued increase of population and decreasing arable land, coupled with the advances in agricultural science and technology, China's surplus labor force, will also be incremented. With the Agricultural productivity level advancing, labor required in the cultivated land will be greatly 
reduced. The number of agricultural labor and land, capital and other resources compared situation no doubt there are a lot of surplus labor in the agriculture (Feng Wen, Sixue Zhao, 2004)

\section{Conclusions}

The transfer of rural labor is the product of the rapid expansion of the initial stage of industrialization since China's reform and opening up. Labor transfer is simple transfer of employment space, the nature of labor force has not changed, still retains its status as farmers, to retain the land, is a "not encouraged farmers to leave their homes, into the factory city" part transfer of rural labor the junior transfer or so-called labor ". The once transfer is characterized that the eastern coastal developed areas are the main inflow areas of labor, labor's own level of education, quality factors,and go out to the employment structure of the labor of the labor force is mainly concentrated in the manufacturing and processing, business services. The inflow of labor mobility performance of the economy is relatively developed areas to the most economically developed regions and backward regions to economically developed areas(Naquin Liu,2005).Rural labor force, "The twice transfer ",also known as the labor transfer again,refers to the rural human capital investment, improve rural labor employment skills and abilities,relying on the market mechanism and policy guidance, realize rural labor from the labor intensive industries to capital, technology intensive industry and burgeoning industry, third industrial transfer,occupation,identity and residence migration flow conversion occur simultaneously, lifestyle produced simple change, enter town and become the self-run occupation of urban residents (Jiafu Chen,2004).

Labor transfer will help to improve the quality of urbanization. With the accelerated pace of China's economic reform, more and more farmers get into the city to make a living, the farmers of a large number going to city,large and medium-sized cities in China entered a rapid period of expansion in the 1990s, China's urbanization level rapid improved, but the quality of urbanization was worrying us (Taizeng Ren, Liuyan Li, 2000)

Review of research literature content.Through the article analyzes and consolidation about the labor transfer,I found that domestic researches of domestic labor transfer analyzed mainly from the 10 aspects:

(1) the status ,problems and countermeasures of the transfer of rural surplus labor force in China;

(2)the factor of restricting the transfer of rural surplus labor force and countermeasures;

(3) industrial restructuring and labor transfer;

(4) the transfer of rural labor in the process of urbanization;

(5) the quality of the peasants on the transfer of rural surplus labor;

(6)the mechanization of agriculture and rural labor transfer;

(7)China's investment in human of agriculture and rural labor transfer;

(8) the development of small towns and agricultural labor force transfer;

(9) agricultural surplus labor transfer problem and outlet in transition period of China;

(10) use comparison of productivity to analysis the transfer of the agricultural labor force in China.

\section{Specifically involved content are summarized}

The existing problems of rural surplus labor force, the constraints of rural surplus labor transfer, the countermeasures of rural surplus labor force transfer.

(1) the transfer point of departure is not standardized, the constraints of the level of agricultural productivity and agricultural burdens, and low farm income. Vigorously develop small towns, the urbanization process.

(2) transfer prominent spontaneous, unorganized, chaotic order. The constraints of the labor itself, 
the quality of the full use of agricultural resources, develop the agricultural potential employment opportunities.

(3) transfer of a single channel, directly under the influence of geographical constraints plus transfer costs. Strong training, improve the comprehensive quality of the rural labor force.

(4) the transfer of regional differences, exacerbated inter-regional inequality of economic development and income. Shortage of funds constraints. Deepen institutional innovation, and ensure the effective transfer of agricultural labor.

(5) rural surplus labor force dispersed, the way transfer biased, the development of township enterprises did not correspond with the capacity of rural surplus labor force. Vigorously promote the industrialization of agriculture.

(6) social environmental constraints of the transfer process. Consolidation and development of township enterprises.

(7) transferred cities' grim employment situation. Establish and improve a unified labor market.

(8) to accelerate the development of tertiary industry.

(9) active in the organized inter-provincial and cross international labor output.

Domestic research on the transfer of rural labor, mostly in reference based on models the combination of the actual situation of China to make some improvements to obtain useful inspiration. Emerged as a growing trend for the transfer of agricultural labor from the depth and breadth of view. The transfer of rural labor issues related to motivation, implementation and development, covering economic development, economic progress, institutional change, industrial change and other factors. Their overall characteristics can be summarized as follows: more on transfer problems, less on study for the transfer of rural labor regional contribution and contribution to the development of farmers and farmers; more on countermeasure research, less to meet farmers to develop; characteristic digital significant of rural labor transfer are more qualitative research, quantitative research is less; multi-reference statistics, and the scope of the study is mainly concentrated in the developed coastal areas; more contribution to the region the rural labor force into and less on rural labor outflow region.Although influence factors of labor Transfer has been comprehensive, because our country is at the dual social and economic transition period, we should close connection with China's labor transfer status and the problems to expand the scope of the study, and deepen the impact of various factors research.Study regarded the focus on the rural labor force for the transfer of rural labor issues as the determinants power of agricultural production and economic development, its total growth, sector allocation, the overall level of quality and the use of reasonable have close relationship with if the rural economy can sustained, stable and healthy develop, relate to the goal of building a moderately prosperous society. Future research should aim at how to effectively carry out the transfer of rural labor training, overall planning, integration of resources, and innovative mechanisms to strengthen the rural labor supply and demand resources system, as well as skills training system, the output service system and so on.

\section{Acknowledgements}

Project of Shandong Provincial Bureau of statistics 2016(KT16133); Shandong social science program(15CSGZ15)

\section{References}

[1] D.W.Jorgenson.The Development of a Dual Economy[J].The Economic Journal,1961.

[2] [U.S.] John C.H.Fei, Gustav Ranis. The development of labor-surplus economy, [M] Beijing: China Press, 1989. 
[3] Lewis. Dual economy theory [M]. Beijing: Beijing Institute of Economics Press,1989.

[4] Nong Zhu. "China's rural labor mobility and the" three rural "problems", Wuhan University Press, 2002

[5] Feng Wen, Sixue Zhao. "Structural surplus labor transfer to explore" [J] population of the Northwest 2004

[6] Jiafu Chen. do not underestimate the rural labor force, "twice transfer", "Chinese township and village enterprises [J].2004 